\title{
Effect of Exercise and Kelussia Odaratissma Mozaff on the Expression of Atrogin-1 Gene in Cardiac Tissue of Obese Rats
}

\author{
Raziyeh Mahmodi $^{1}$ iD , Hossein Sazegar $^{1^{*}}$ (D) \\ ${ }^{1}$ Dept of Biology, Faculty of Sciences, Shahrekord Branch, Islamic Azad University, Shahrekord, Iran
}

\section{Article Info}

Article type:

Research article

\section{Article History:}

Received: 03 February 2021

Revised: 22 February 2021

Accepted: 21 June 2021

\section{* Correspondence to: \\ Hossein Sazegar \\ Dept of Biology, Faculty of Sciences, \\ Shahrekord Branch, Islamic Azad \\ University, Shahre-kord, Iran \\ Email: h.sazgar@iaushk.ac.ir}

\author{
A B S T R A C T
}

Introduction: The Atrogin-1 gene is selectively expressed only in muscle tissue. Considering the importance of the Kelussia and Atrogin-1 gene, this study aimed to investigate the effect of exercise and Kelussia on the expression of Atrogin- 1 gene in the heart tissue of obese rats.

Material \& Methods: In total, 30 adult male Wistar rats weighing 180 to $200 \mathrm{~g}$ were selected and divided into five groups of control, negative control (obese mice), two treatment groups receiving doses of 400 and 800 $\mathrm{mg} / \mathrm{kg}$ of Kelussia extract, and a group of obese mice along with exercise. It should be noted that a rat treadmill was used in which the rats were placed on the device five days a week for one hour. Atrogin-1 gene expression was assessed using Real-time (RT)-PCR technique, and finally, the results were analyzed using SPSS software through an independent t-test. A p-value less than 0.05 was considered statistically significant.

(Ethic code: IR.IAU.SHK.REC.1399.050)

Findings: The results showed that Kelussia extract at a dose of $800 \mathrm{mg} / \mathrm{kg}$ could significantly reduce the expression of Atrogin- 1 gene $\left(1.15 \pm 0.33^{\mathrm{b}}\right)$, compared to $400\left(1.27 \pm 0.50^{\mathrm{ab}}\right)$ and the obese group. On the other hand, the group of mice with exercise also had a significant decrease in Atrogin1 gene expression, compared to the obese group $\left(1.75 \pm 0.84^{\mathrm{ab}}\right)$. The results of biochemical tests also confirmed the improvement of the heart of obese mice with $800 \mathrm{mg} / \mathrm{kg}$.

Discussion \& Conclusion: Kelussia due to compounds, such as flavonoids, can reduce the expression of Atrogin-1 gene. If it is confirmed in future studies, it can be a therapeutic target in the hearts of obese people.

Keywords: Atrogin-1 gene, Kelussia, Heart tissue, Obesity

$>$ How to cite this paper

Mahmodi R, Sazegar H. Effect of Exercise and Kelussia Odaratissma Mozaff on the Expression of Atrogin-1 Gene in Cardiac Tissue of Obese Rats. Journal of Ilam University of Medical Sciences. November 2021;29(4): 83-92. 


\section{بررسى اثر تمرينات ورزشى و كرفس كوهى بر بيان زن Atrogin-1 در بافت قلب}

\section{موش هاى صحرايى : جاق}

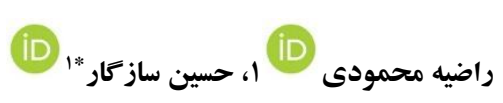
'خروه زيستشناسى، دانشكده علوم پايه، دانشكاه آزاد اسلامى، واحد شهر كرد، شهركرد، ايران

اطلاعات مقاله

مقدمه: زن Atrogin-1 بهصورت انتخابى، تنها درون بافتهاى ماهيجهاى بيان مىشود. با توجه به اهميت گياه كرفس و زٔن نوع مقاله: يزوهشى هtrogin-1 هاى صحر ايى جاق است.

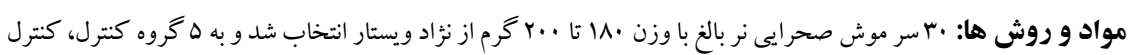

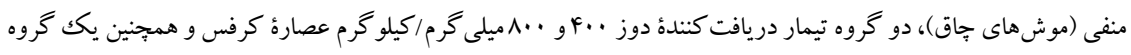

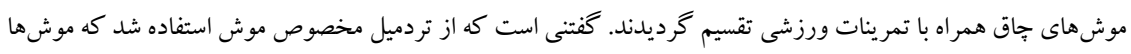

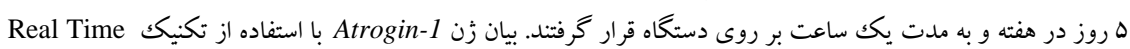

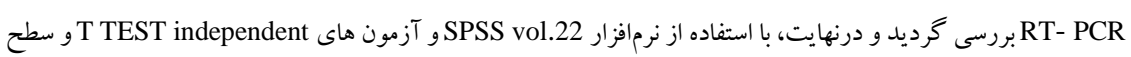
معنى

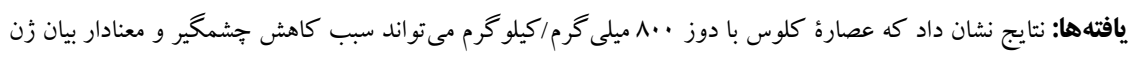

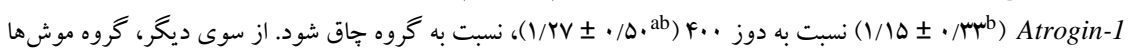

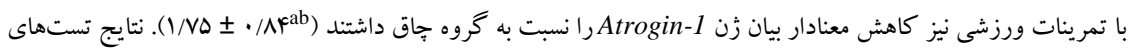

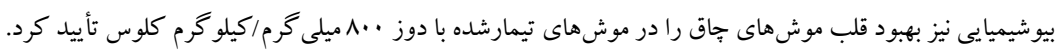

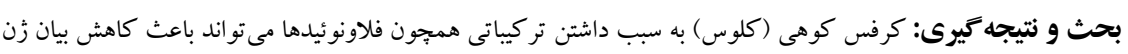
Atrogin-1

تاريخ دريافت:

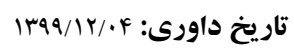

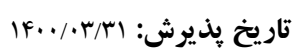

$$
\text { حويسنده مسئول: }
$$
كروه زيستشناسى، دانشكده علوم

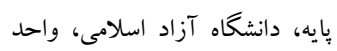

$$
\text { شهر كرد، شهركرد، ايران }
$$

Email:

h.sazgar@iaushk.ac.ir

وازههاى كليدى: كرفس كوهى، زن Atrogin-1، بافت قلب، بيمارى جاقى

< استناد: محمودى، راضيه؛ ساز كار، حسين. بررسى اثر تمرينات ورزشى و كرفس كوهى بر بيان زن Atrogin-1 در بافت قلب موش هاى صحرايى جاق.

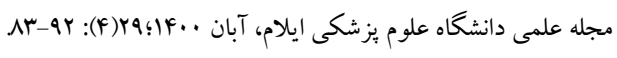


ايزومرهاى FOXO فعال شوند و از سيتوزل به هسته جابجا كردند، سبب فعال شدن دو زٔن به نامهاى رينگك فينخر عضلانى ا MuRF1) و اف باكس ( - MAFbx/atrogin-

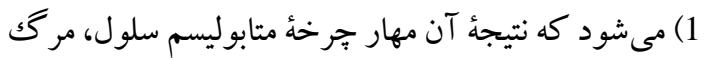
سلولى و آغاز تخريب بافت قلبى خواهد بود (V) (V (V). atrogin- 1 نيز شناخته مى بوده، در بهنو 1 MAFbx

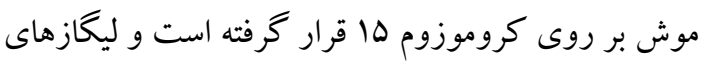

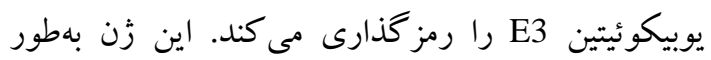
تخصصى، در عضلات اسكلتى و قلبى بيان مى شود و در

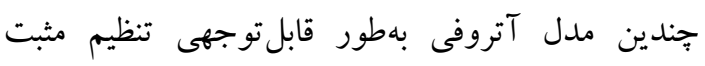

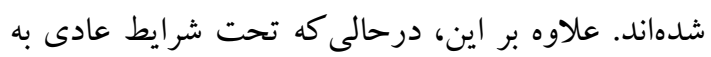

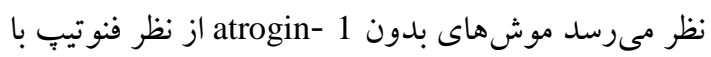

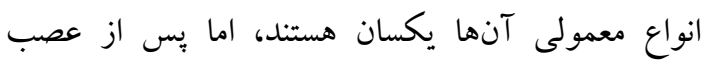
بردارى، اين حيوانات در برابر آتروفى عضلانى اندكى از ازفال خود محافظت نشان مىدهند (A). با توجه به افزايش دانش بشرى، نياز براى يافتن

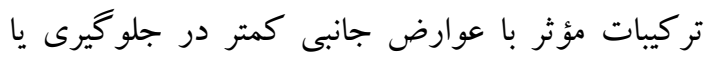

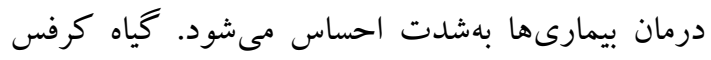

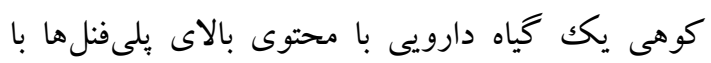
خاصيت آنتىاكسيدانى محسوب مىشود كه خواص كاهشدهندة استرس اكسيداتيو و حفاظت بافتهاى متابوليكك بدن در برابر آسيبهاى شيميايى را دارد. علاوه بر اين، تجويز اين گياه سبب كاهش سطح يراكسيداسيون

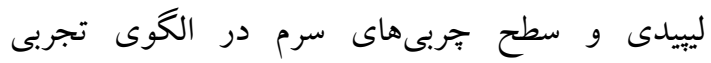
هييرليييدمى در موجودات آزما يشكاهى با استفاده از تجويز خوراكى رزيم غذايى يرجربى به مدت ب ماه مى گردد (9).

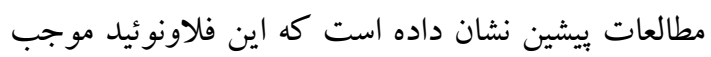
مهار متابوليسم آراشيدونيك اسيد مىشود؛ همجنين وجود

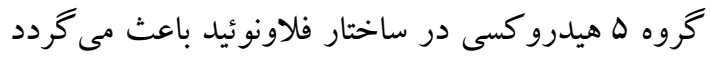

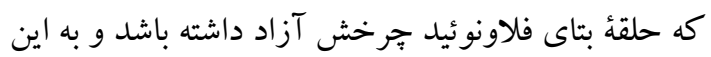

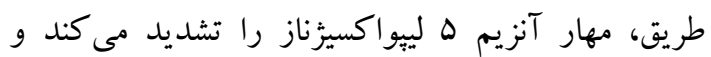

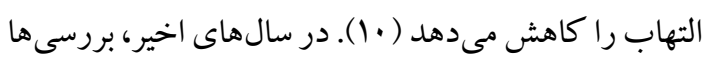
بر روى گياه كرفس بيانخر آن است كه عصاره اين گياه

\section{مقدمه}

در كشورهاى توسعهيافته، جاقى بهعنوان يكى از مهم ترين اختلالات تغذيهاى محسوب مىشود. ارتباط ميان

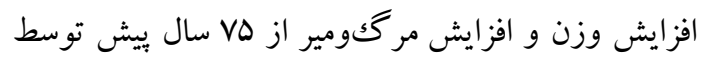
صنعت بيمه عمر شناختهشده بود. جاقى بهعنوان يكك عامل

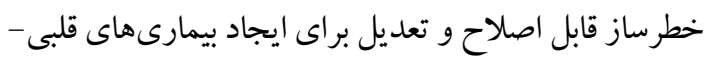

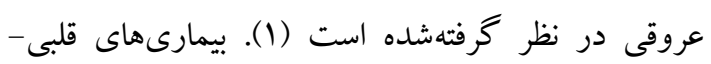

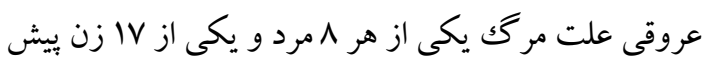

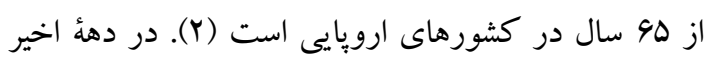

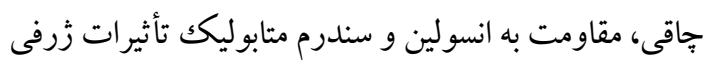
بر سلامت مردم كشورهاى درحالتوسعه ايجاد كردهاند،

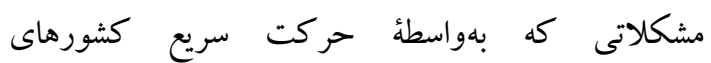

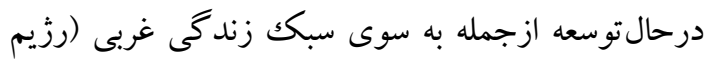
غذايى، بى حركتى و مصرف سيگار) ايجادشده است. افزايش انسولين خون بهصورت جبرانى ناشى از مقاومت به انسولين در افر اد جاق موجب اختلالات جربى خون، افزايش فشارخون و ديابت قندى مى شود كه هريك به تنهايى و يا در ارتباط باهم، بهعنوان عوامل خطرساز ابتلا به بيمارىهاى قلبى - عروقى به شمار مى روند (r). در كشورهاى درحالتوسعه، بهواسطة وجود تفاوت آشكار در طبقات اجتماعى و اقتصادى و عادتهاى اشتباه بهداشتى، روند

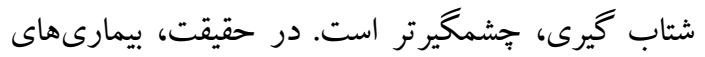

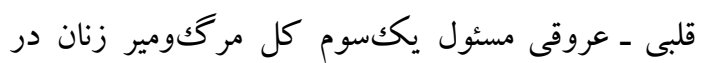
سراسر دنيا و عامل نيمى از مرگكوميرها ميان زنان كشورهاى درحال توسعه هستند (F).

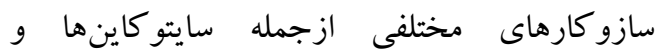

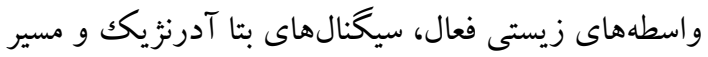

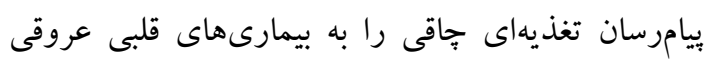

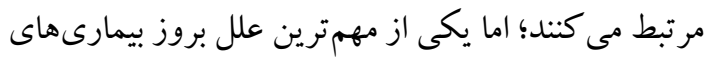

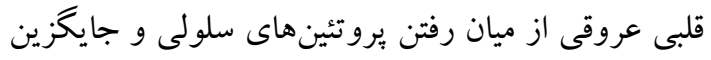
شدن كلازنها به جاى سلولهاى ازدسترفته است (ه).

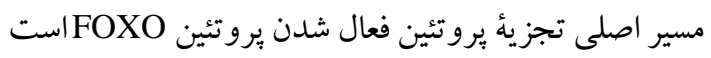

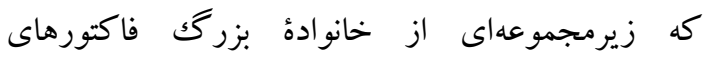

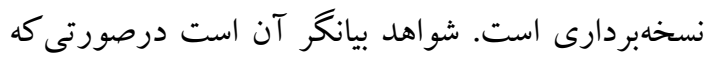


برابر با F/V كيلو كالرى در هر گرم (YF درصد جربى درصد بروتئين و أF درصد كربوهيدرات) بود. وزرش د/دن رتها: براى تمرينات ورزشى از تردميل مخصوص موش استفاده كرديد كه رتها ها روز در هفته و به مدت يكك ساعت بر روى دستخاه قرار گر فتند. تهيئ عصارة كرفس: كياه كرفس از مناطق كوهستانى مدنظر در استان جهارمحال و بختيارى جمع آورى و با تأييد متخصصين كياهيزشكى دانشگاه آزاد شهر كرد تأييد شد و در محلى كه دور از نور و آفتاب و در دماى رطوبت مناسب بهطورى كه هوا در آن محل جريان داشته باشد، نخههارى و خشك گرديد؛ سيس با آسياب برقى، به قطعات ه/ • تا س سانتى يودر شد و سيس •ه گرم از اين بودر را با الكل اتانول • درصد صنعتى مخلوط كرديد، بهاندازهاى كه له يودر كامل با الكل بوشيده شود و الكل تا روى گياه بيايد و بعد از هاعت، از كاغذ صافى عبور داده شد. عصارهاى كه بֶ از عبور از كاغذ صافى به دست آمد، با دستگاه Rotary خود دستخاه شرايط ايدهآل را ايجاد مى كند، تغليظ كرديد. درنهايت، مقدار انتخابى عصارهها با حل كردن آنها در يكك حلال مناسب بهدست آمد و بهصورت گاوازّ به رتها داده شد. پس از كذشت يكك ماه از فرايند كاواز و تيمار، رتها در شرايط كاملاً بهداشتى، با استفاده از كلروفورم بيهوش كرديدند و با استفاده از ست جراحى شكم آنها باز و كبدشان برداشته شد.

استخراج RNAو سنتز DNA. در تحقيق حاضر، براى استخراج RNA تام از ترايزول (Invitrogen ساخت كشور امريكا) مطابق بروتكل استفاده گرديد و بس از استخراج RNA استخراجشه از لحاظ كيفى و كمى بررسى شد. براى حذف آلودگى احتمالى RNA استخراجشده به DNA زنومى، هر نمونه RNA استخراجشه با آنزيم DNaseI در دماى MV درجه سانتى گراد تيمار گرديد و بهمنظور خنىىسازى آنزيم DNaseI هر نمونه با ا ميكروليتر اتيلن دى آمين تترا استيكك اسيد (EDTA مركك ساخت كشور
باعث كاهش سطح كلسترول تام و بالا بردن ترى كليسريد

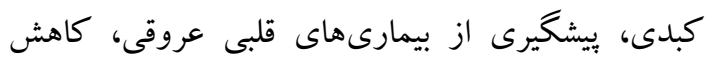
غلظت كلوكز و كراتينين در موشهاى ديابتى، كاهش فشارخون، يرقان و تقويت قلب مىشود؛ همجنين آثار ضدقارجى و ضدباكتريايى نيرومندى دارد. فلاونوئيدها بر فعاليت تيروئيدى اثر مهارى داشته و خطر هييو تيروئيديسم را افزايش مىدهند (1)؛؛ بنابراين، با توجه به اهميت گياه كرفس و زن Atrogin-1، هدف از اين بزوهش بررسى اثر Atrogin-1 تمرينات ورزشى و كرفس كوهى بر بيان زن در بافت قلب موش هاى صحر ايى جاق است.

\section{مواد و روش ها}

نوع مطالعه و نمونه كيرى: مطالعه حاضر تجربى و روش كردآورى اطلاعات بهصورت آزمايشخاهى - مشاهدهاى بود. در اين بررسى، ·r سر رت نر بالغ ويستار با ميانخين

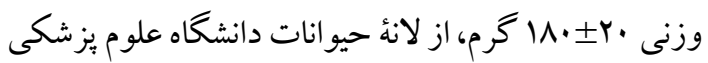
شهر كرد خريدارى شد. اين حيوانات آزمايشگاهى در

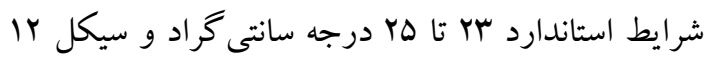
ساعت روشنايى و Yl ساعت تاريكى با آب و غذاى كافى سلى و استاندارد درون قفسهاى مخصوص دانشگاه آزاد اسلامى واحد شهر كرد نكهدارى گرديدند. رتها يس از ساز گارى با محيط، بهطور تصادفى به ها گروه 9 تايى تقسيم شدند. كروهبندى حيوانات شامل ا. كنترل، Y. كنترل منفى (موشهاى جاق بدون تيمار)، ب. گروه A (موش هاى جاق

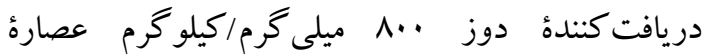
كلوس)، F. Fروه B (موشهاى جاق دريافت كننده دوز

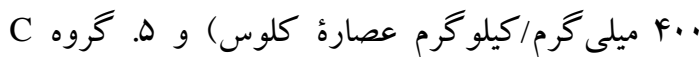
(موشهاى جاق همراه با تمرينات ورزشى) بود. پس از گروهبندى و بس از طى شدن دوره تطبيق حيوانات با حرارت و رطوبت محل نكهدارى، آزمايش ها آغاز شد. در ضمن اصول اخلاقى كار با حيوانات آزمايشگاهى در همء مراحل لحاظ كرديد. جاق كردن رتها: رتها به مدت 4 هفته با رثزيم غذايى با جربى بالا جاق شدند كه شامل ها درصد جربى 
جدول ا. برايمرهاى موردنظر

\begin{tabular}{|c|c|c|c|}
\hline 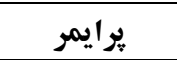 & توالى يرايمر & دماى اتصال (C') & سايز باند (bp) \\
\hline Atrogin1-R & 5'- CGCTCCTTAGTACTCCCTTTGTG-3' & 94 & 194 \\
\hline Atrogin1-F & 5' - CTTGGATGAGAAAAGCGGCAC-3' & & \\
\hline GAPDH-F & 5' - TGATTCTACCCACGGCAAGTTC-3' & $\Delta 9$ & r.. \\
\hline
\end{tabular}

gene 6000 بهنظور سنجش كمى سطح بيان زُنهاى

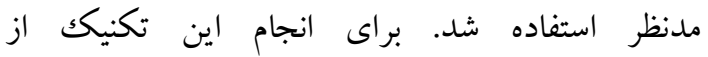
SYBR Green كرديد و درنهايت، بس از محاسبه هدف در نمونهُ مدنظر (بيمار) نسبت به نمونه كنترل (سالم)

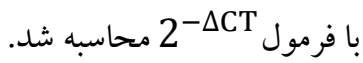

تستهاى بيوشيمياين: در تحقيق حاضر، تستهاى بيوشيميايى شامل تست كلسترول، قند، HDL و LDL بود

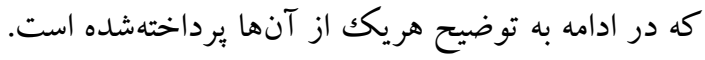

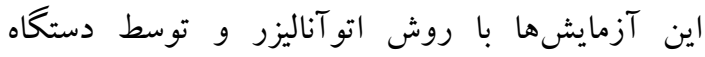
اتو آناليزر (Auto Analyser BT 3000plus)، ساخت كشور ايتاليا) صورت كرفت. Tاناليزهاى Tمارى: آناليز آمارى با استفاده از نرمافزار

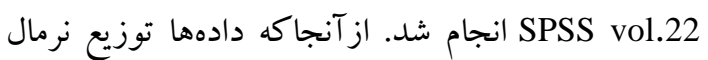

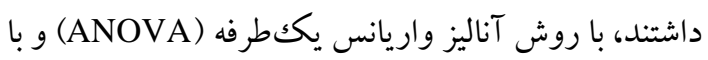

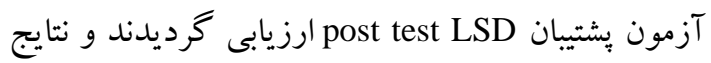
بهصورت Mean I SEM ارائه و تفاوت ميان خروههاى مختلف با P<0.05 معنادار تلقى شد.

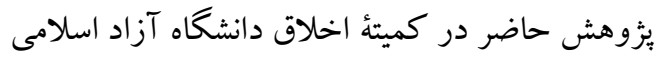
واحد شهر كرد با كد تصويب رسيده است.

\section{يافته ها}

بررسى كمى وكيفيت RNA/ستخراجشده بر روى زل

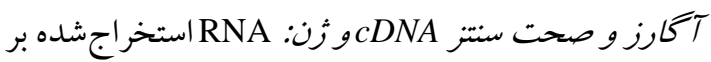

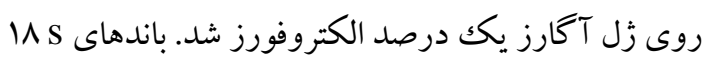
و Y S S بهطور واضح قابل تشخيص بود كه نشاندهندة سالم بودن RNAاست كه در شكل شمارهٔ ا. الف نشان دادهده
آلمان) تيمار و به مدت ·1 دقيقه در دماى ه9 درجه

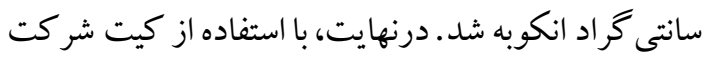
يكتا تجهيز آزما و يرايمر 9 نو كلئوتيدى تصادفى، طبق يروتكل كيت، cDNA هر نمونه سنتز گرديد. بهمنظور بررسى ميزان بيان زنهاى مدنظر، يرايمرهاى

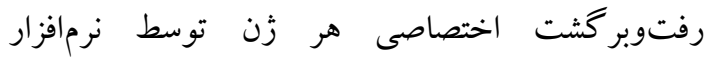
BeaconDesigner vol.8.0 شد و پِ از BLAST در پِيكاه اينترنتى NCBI، توسط شر كت بيشگام سنتز گرديد كه در جدول شمارئ آ آورده

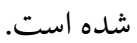
تكنيك RT-PCR: در اين بررسى، براى تأييد صحت

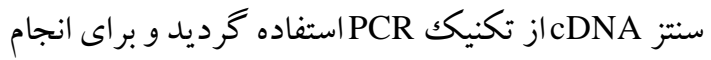
تكنيك، ·ل ميكروليتر PCR Master Mix (يكتا تجهيز

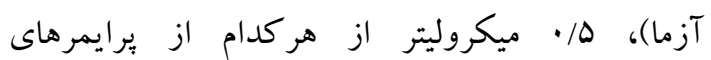

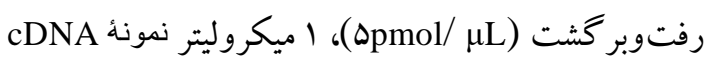

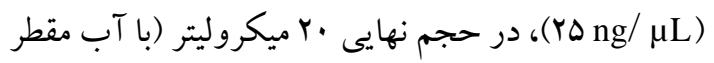
استريل) تهيه و مخلوط شد. در ادامه، با برنامهُ دمايى:

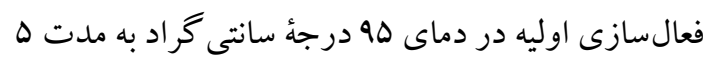

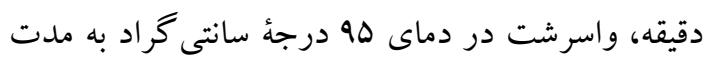

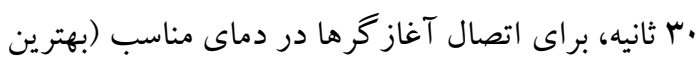
دما براى انجام PCR براى زن GAPDH مرجهُ

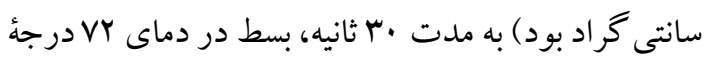

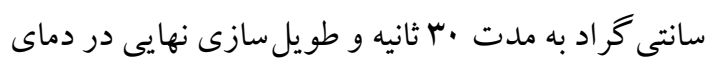

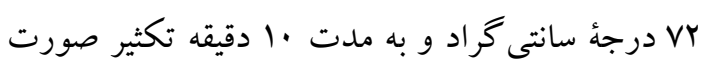

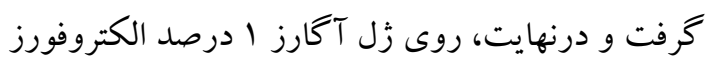
انجام كرديد. تكنيك Real time RT-PCR: در بيزوهش حاضر، از Corbett rotor (دستكاه Real Time-RT PCR تكنيك 


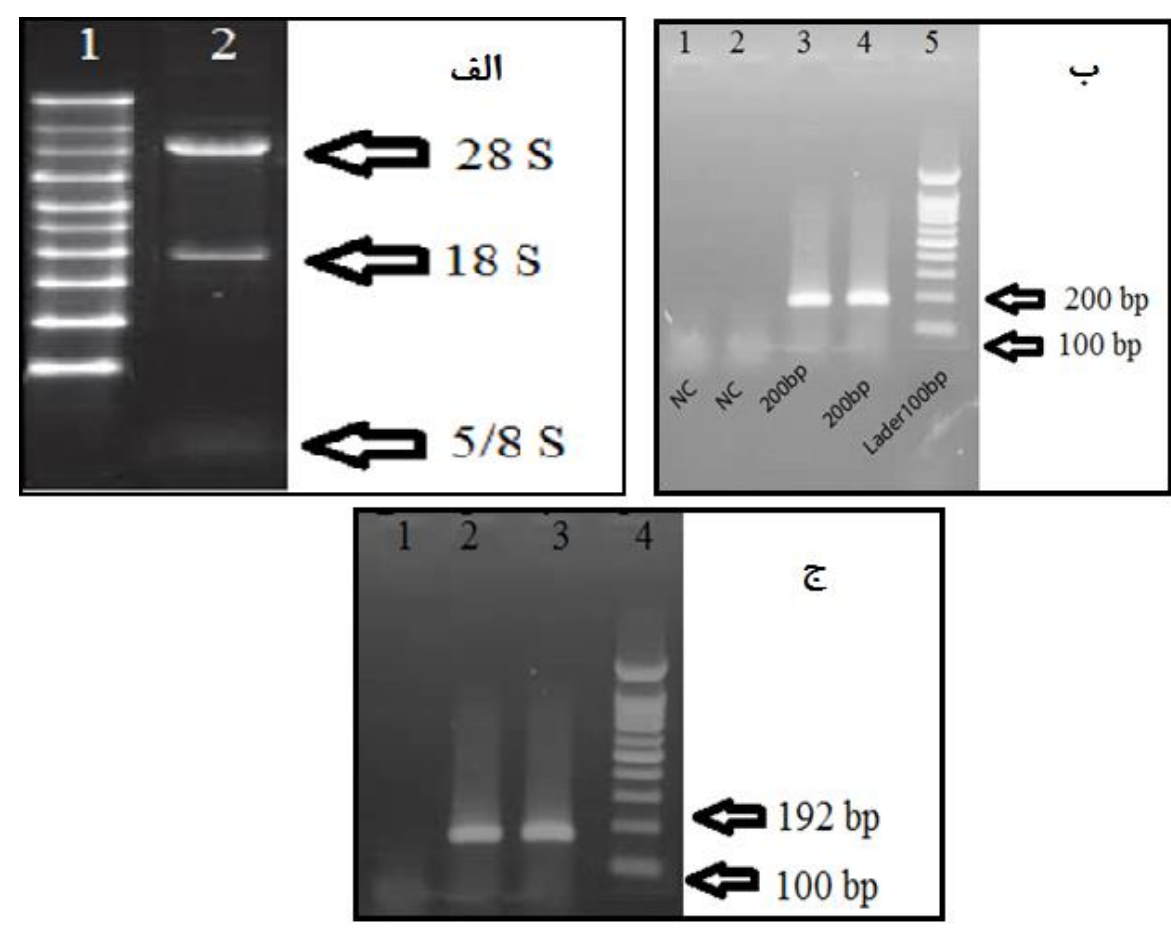

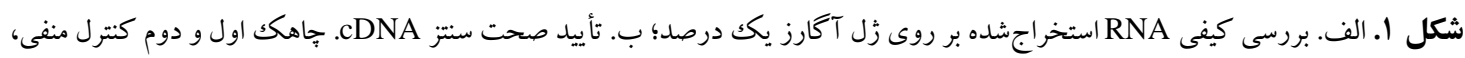

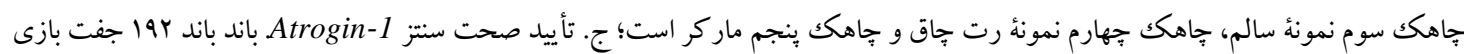

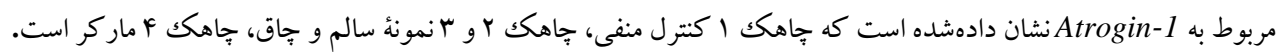

\section{به Atrogin-1 نشان داده شده است.}

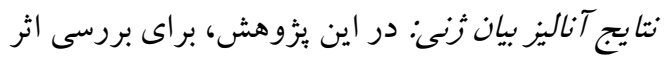

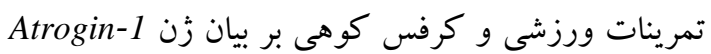
در بافت قلب موشهاى صحر ايى جاق، دادههاى حاصل از بيان زن به روش real time RT-PCR با استفاده از آزمون Tارى T-test independent و سطح معنادارى

$$
\text { انجام شد. }
$$

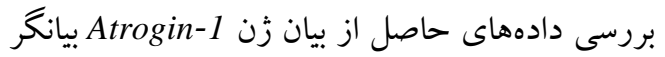

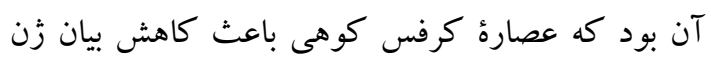
Atrogin-1

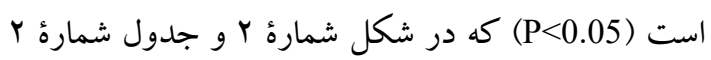
نشان دادهده است. عصارة كرفس كوهى باعث كاهش

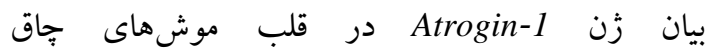

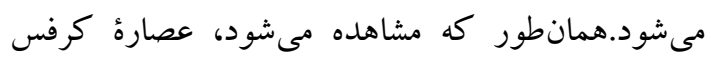

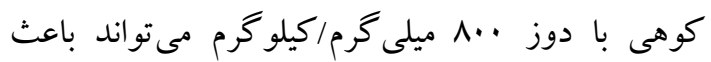

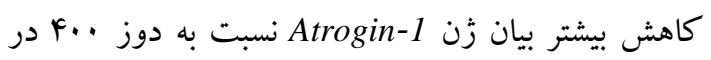

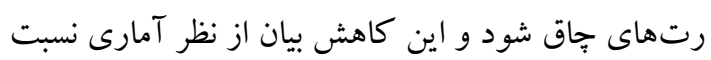

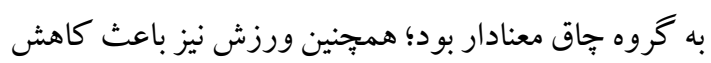

RNA است؛ همجنين مقدار ا ميكروليتر از هر نمونه

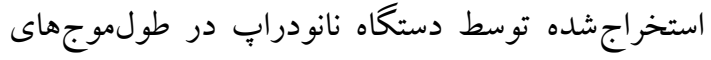

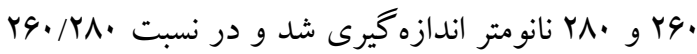

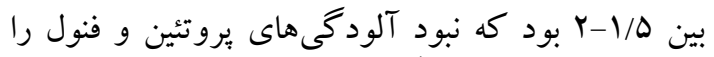
نشان داد. زن GAPDH در همة شرايط و در تمام سلولها

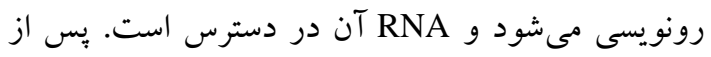

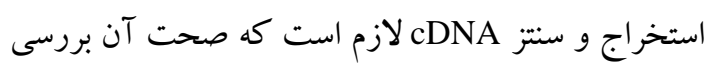
كردد كه بهنظور تأييد صحت سنتز cDNA با يرايمرهاى اختصاصى زن GAPDH، واكنش PCR انجام شد. بـ إس از

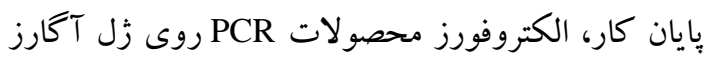

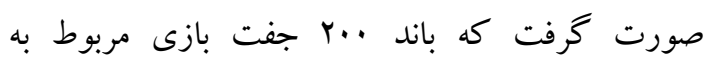
GAPDH زن نشان دادهشه است. در اين تحقيق، تأييد صحت سنتز Atrogin-1 بال ير ايمرهاى اختصاصى آن واكنش RT-PCR انجام شد و و

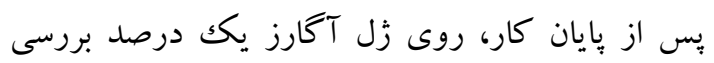

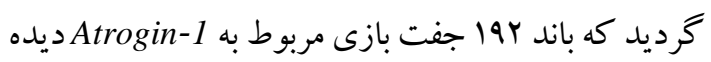

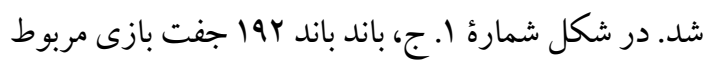




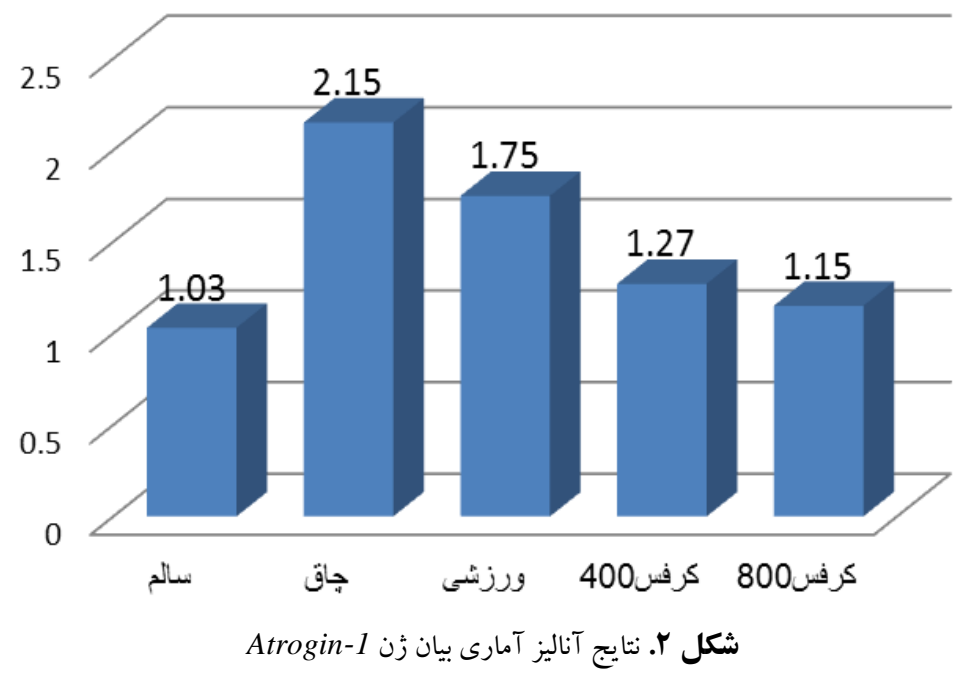

جدول rا. مقايسٔ ميزان تغييرات بيان زُن atrogin در گروههاى مختلف

\begin{tabular}{|c|c|c|c|c|c|}
\hline 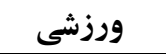 & عصارهُ كرفس •. & عصارة كرفس ·. & بيمار & سالم & كروه \\
\hline $1 / \mathrm{V} \Delta \pm \cdot / \mathrm{A} \mathrm{F}^{\mathrm{ab}}$ & 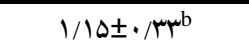 & $1 / Y V \pm \cdot / \Delta \cdot a b$ & $r / / \Delta \pm \cdot / N^{\mathrm{a}}$ & $1 / \cdot r \pm \cdot / r q^{b}$ & بيان زُن \\
\hline
\end{tabular}

بود كه در شكل شمارة ب نشان دادهشده است. همانطور

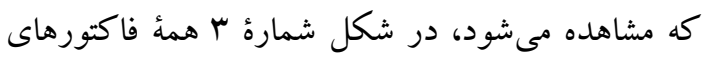

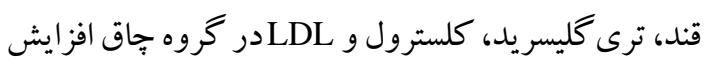

بيان زن Atrogin-1 نسبت به گروه جاق مىشود. نتايج تستهاى بيوشيمياين: تستهاى بيوشيميايى تحقيق حاضر شامل تست كلسترول، قند، HDL و LDL

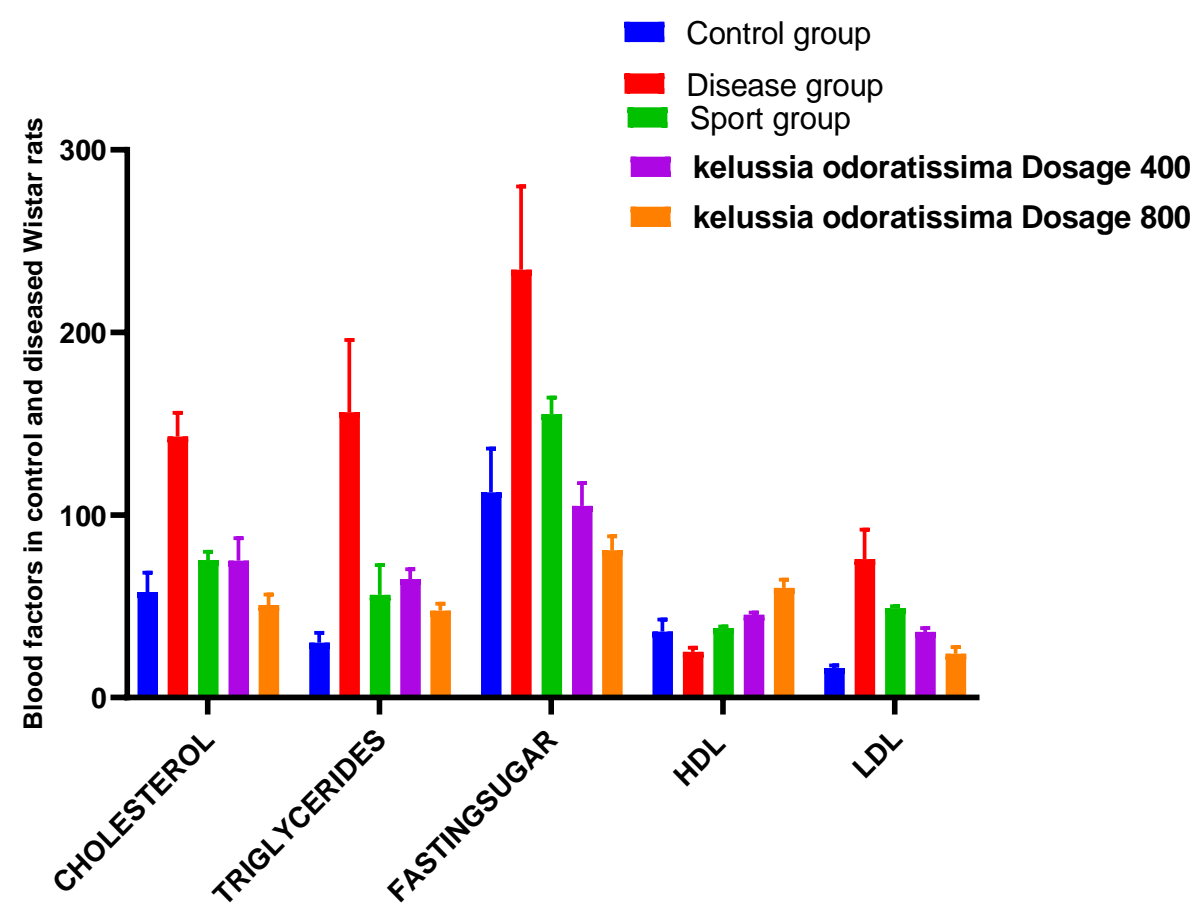

شكل "ا. نتايج تستهاى بيوشيميايى كلسترول، قند، HDL و و و ترى كليسريد در گروههاى تيمار، ورزشى، بيمار و كتترل 
مىتواند بهعنوان يكك هدف درمانى در بيمارى جاقى و

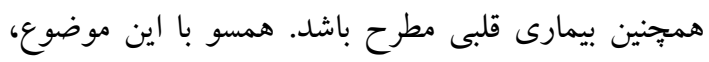

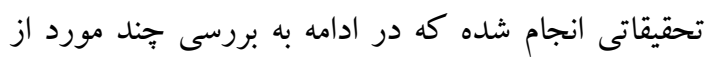

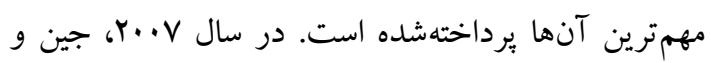

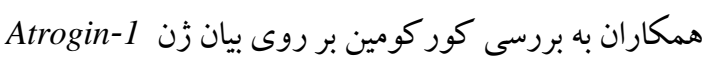

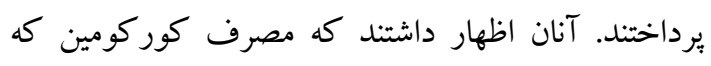

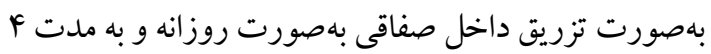
روز به موشها، باعث كاهش معنادار Atrogin-1 در موشها

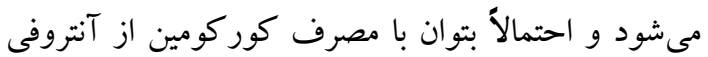
عضلانى ناشى از جاقى با مهار مسير آتروفى عضله استفاده

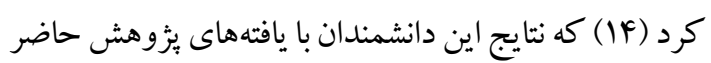

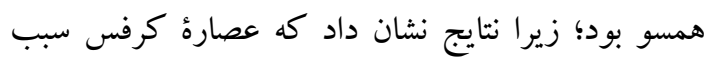

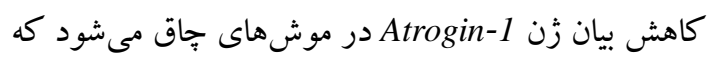

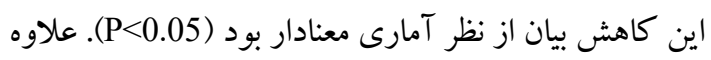
بر اين، نتايج روى موشهاى جاق نشان داد كه عصارة

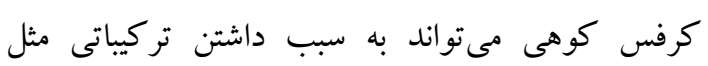

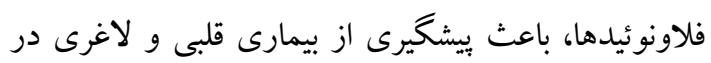

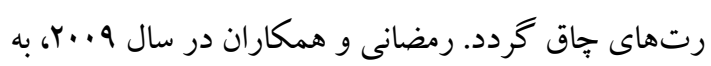

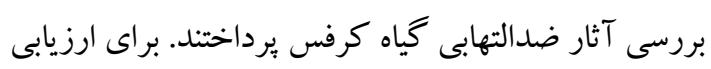

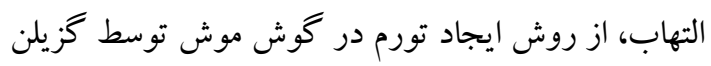

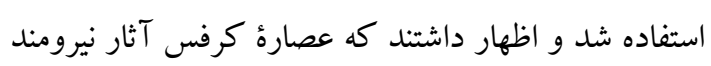
ضدالتهابى حتى در دوزهاى بايين دارد كه احتمالاً به علت

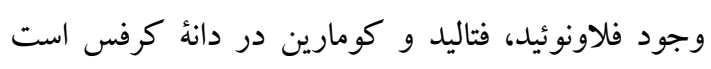

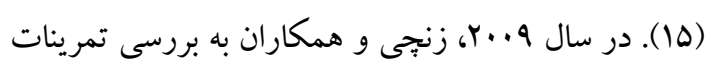
ورزشى و بيان زن Atrogin-1 در موشها يُ هرداختند. نتايج

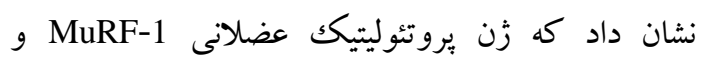
Atrogin-1

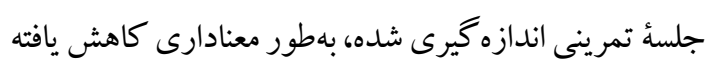
است (19). در يزووهش حاضر نيز نتايج نشان داد كه عصارة

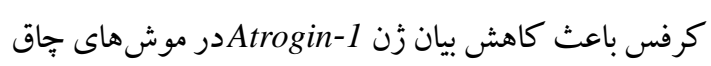

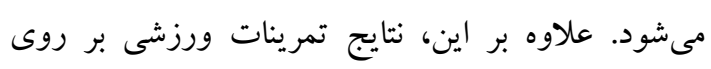

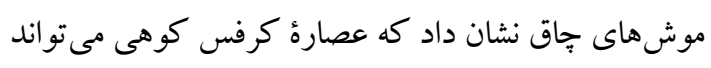

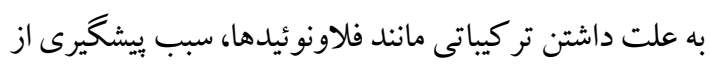
بيمارى قلبى و لاغرى در رتهاى جاق و باعث كاهش بيان
يافته كه پِ از تمرينات ورزشى در گروه ورزشى و

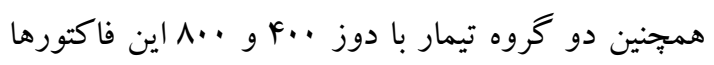
كاهش يافته است. همانطور كه مشاهده مى دودو، عصارة

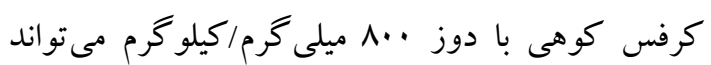

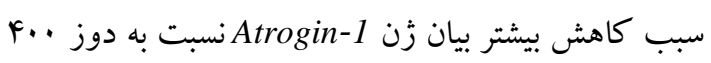

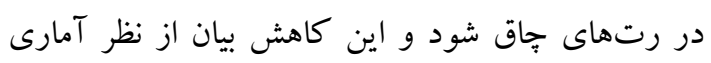
نسبت به گروه جٍاق معنادار بود (P<0.05)

\section{بحث و نتيجه كيرى}

كياه كرفس كوهى يكك گياه دارويى با محتوى بالاى

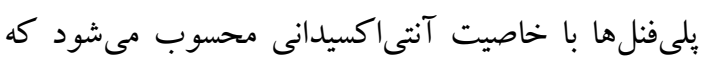
خواص كاهشدهندة استرس اكسيداتيو و حفاظت بافتهاى

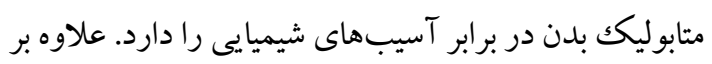

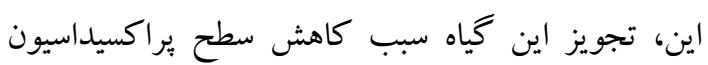

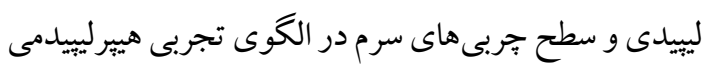
در موجودات آزمايشكاهى با استفاده از تجويز خوراكى دريى

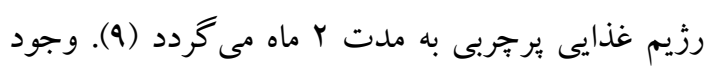

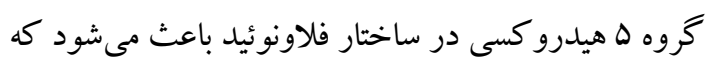

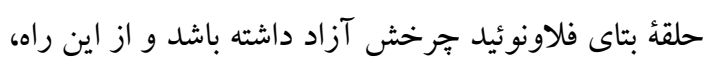

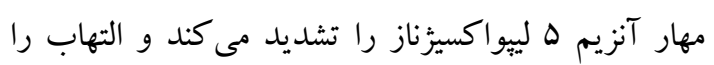

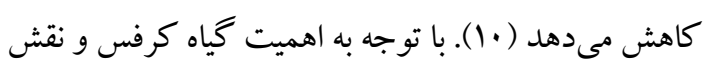

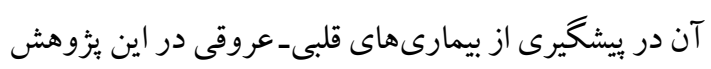

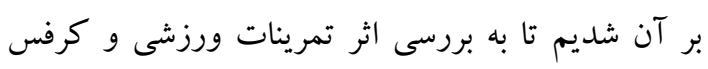

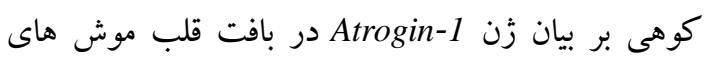

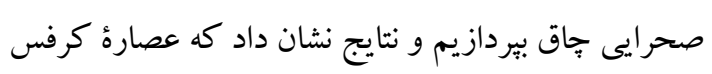

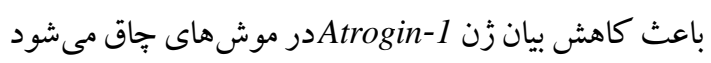
كه اين كاهش بيان از نظر آمارى معنادار بود (P<0.05)

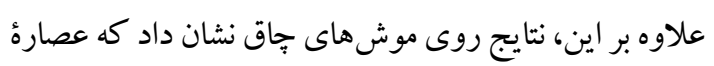
كرفس كوهى مى تواند به علت داشتن تركيباتى مانند

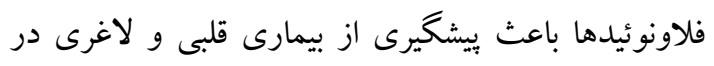

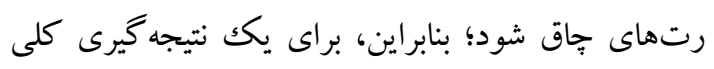

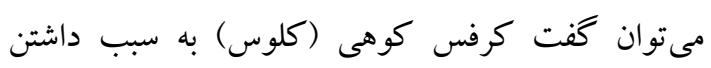



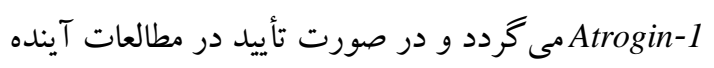


رونويسى و ساير بروتئينهاى هسته بهمنظور يوبيكوئيتينه كردن و تجزئ آنها است. از سوى ديخر، تحقيقات بر برون

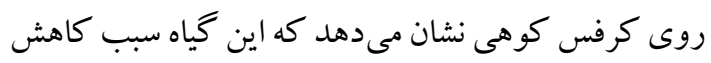

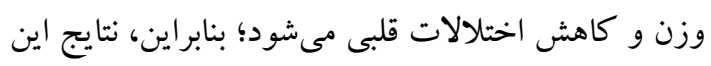

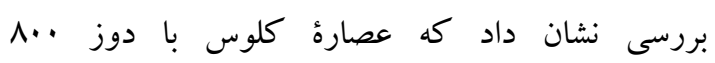

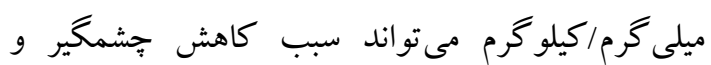

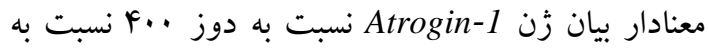

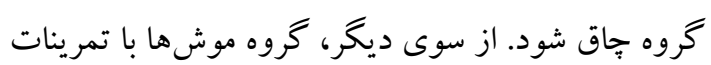
ورزشى نيز كاهش معنادار بيان زن Atrogin-1 را نسبت به كروه جاق داشتند. نتايج تستهاى بيوشيميايى نيز بهبود قلب موشهاى جاق را در موشهاى تيمارشده با دوز ..

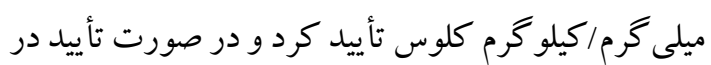

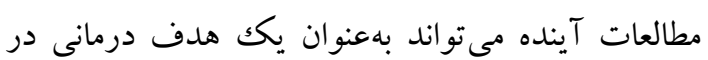
بيمارى جاقى و همجنين بيمارى قلبى مطرح باشد.

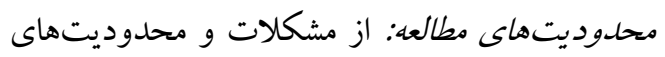

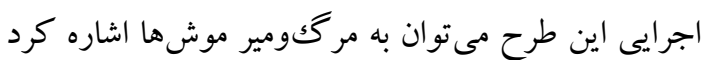

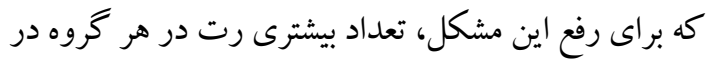

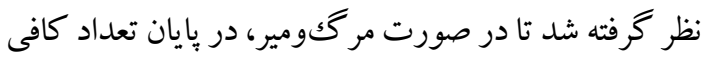
رت در هر گروه براى آناليز آمارى وجود داشته باشد.

\section{تشكر و قدردانى}

اين بررسى برگرفته از بِايانامهُ كارشناسى ارشد و و

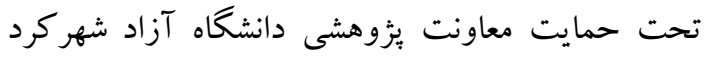
است و بدينوسيله نويسندگان از همة افرادى كه در

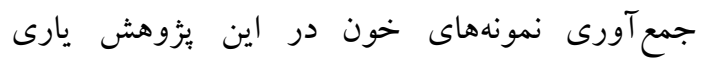
رساندند، كمال تشكر و قدردانى را دارند.

تعارض منافع نويسند كارض منافع اعلام مى كنند كه تضاد منافعى در اين

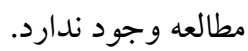

كد اخلاق: IR.IAU.SHK.REC.1399.050
زن Atrogin-1 گردد. در سال 19 •rا، دانگك و همكاران به بررسى بيان زن Atrogin-1 در سنجابها يرداختند. آنان

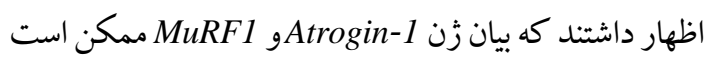
براى جلو گيرى از آتروفى SOL از طريق كنترل تعديل

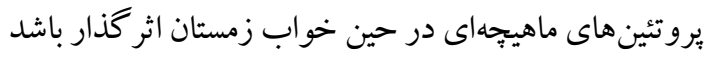
(IV) افزودن يودر كرفس كوهى به رزيم غذايى مبتلايان به

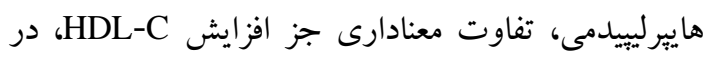

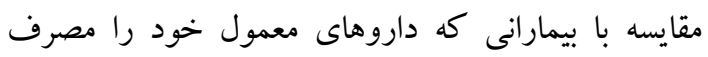

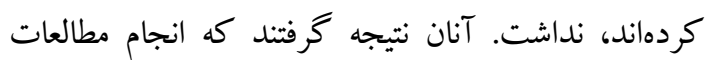
طولانىمدت دربارة اثر آنتىاكسيدانهاى طبيعى بر روى تردي

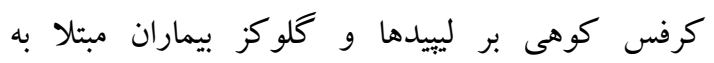
هاييرليييدمى ضرورى بهنظر مىرسد (1) (1). با توجه به نتايج

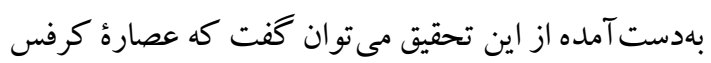

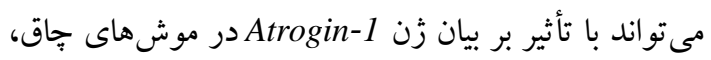

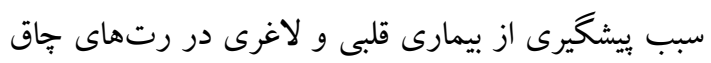

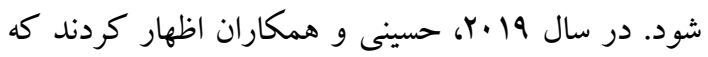
مصرف كوركومين باعث كاهش معنادار Atrogin-1 در

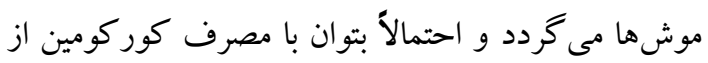

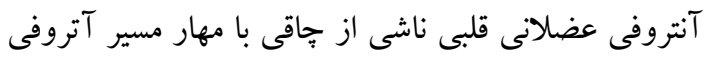
عضله استفاده كرد (19).

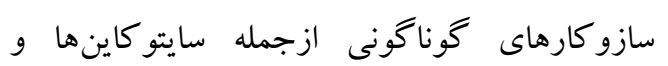

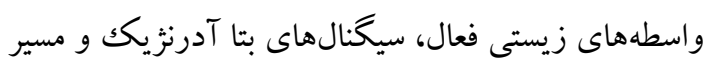

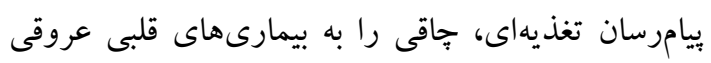

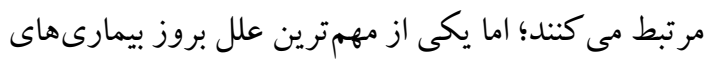

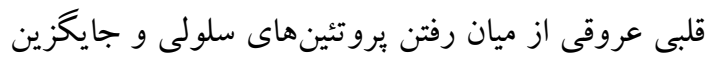
شدن كلازنها بهجاى سلولهاى ازدسترفته است. Atrogin- 1 نيز شناخته مى بهود، 1 MAFbx

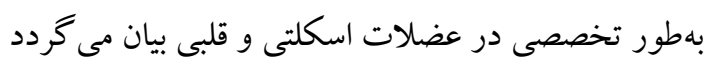
و در جندين مدل آتروفى بهطور قابل توجهى تنظيم مثبت

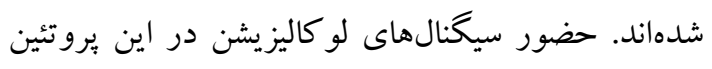

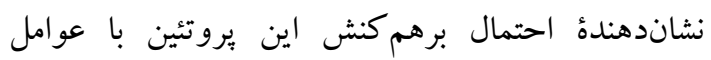




\section{References}

1. Eckel RH, Krauss RM. American Heart Association call to action: obesity as a major risk factor for coronary heart disease. Circulation 1998;97: 2099100. doi.10.1161/01.CIR.97.21.2099

2. Allender S, Scarborough P, Peto V, Rayner M, Leal J, Luengofernandez R, et al. European cardiovascular disease statistics. European Heart Network2008;3: 11-35.

3. Samiee RF, Ziaee A, Qambarian A, Mirmiran P, Momenan A, Azizi F. [Association between risk factors of cardiovascular diseases and obesity among Tehranian Women]. TLGSJ2012;2:1-20. (Persian)

4. Pilote L, Dasgupta K, Guru V, Humphries KH, Mcgrath J, Norris C, et al. A comprehensive view of sex-specific issues related to cardiovascular disease. CMAJ2007;176: 1-44. doi.10.1503/cmaj.051455

5. Perl A. Mtor activation is a biomarker and a central pathway to autoimmune disorders, cancer, obesity, and aging. Ann Newyork Acad Sci 2015;1346: 33. doi.10.1111/nyas.12756

6. Milan G, Romanello V, Pescatore F, Armani A, Paik $\mathrm{JH}$, Frasson L, et al. Regulation of autophagy and the ubiquitin proteasome system by the foxo transcriptional network during muscle atrophy. Nature Com2015;6: 6670. doi.10.1038/ncomms7670

7. Martins R, Lithgow GJ, Link W. Long live foxo unraveling the role of foxo proteins in aging and longevity. Ag Cell 2016;15: 196-207. doi. 10.1111/acel.12427

8. Bodine SC, Latres E, Baumhueter S, Lai VKM, Nunez L, Clarke BA, et al. Identification of ubiquitin ligases required for skeletal muscle. Atroph Sci 2001;294: 1704-8. doi. $10.1126 /$ science. 1065874

9. Tsi D, Das N, Tan B. Effects of aqueous celery Apium graveolens extract on lipid parameters of rats fed a high fat diet. Plant Med1995;61: 18-21. doi.10.1055/s-2006-957990

10. Kaouadjii M. Nouveaa glycoside befphtalid chezgentiona pedicellata. J Nat Prod. 1986;49: 872-87.
11. Ferreira AC, Neto JC, Silva AC, Kuster RM Carvalho DP. Inhibition of thyroid peroxidase by Myrcia uniflora flavonoids. Chem Res Toxicol 2006;19: 351-5. doi.org/10.1021/tx0501684

12. Rychlik W. Oligo 7 primer analysis software PCR Primer design. 2 th ed. Springer Publication. 2007;P. 35-59. doi.10.1007/978-1-59745-528-2_2

13. Rahimi Z, Salehi M, Dousti A. [CCL2 polymorphism in drug resistant and drugresponsive patients with epilepsy in Isfahan Iran]. Med Lab J 2017;11: 30-4. (Persian)

14. Jin B, Li YP. Curcumin prevents lipopolysaccharide induced atrogin $1 / \mathrm{MAFbx}$ upregulation and muscle mass loss. J Cell Biochem2007;100: 960-9. doi.10.1002/jcb.21060

15. Ramezani M, Nasri S, Yassa N. Study of anti inflammatory effect of aqueous and hexane extract of Apium graveolens L. in Mice. Iranian J Med Arom Plants 2009;24: 437-43. doi.cabdirect/abstract/20093145047

16. Zanchi NE, Siqueirafilho MA, Lira FS, Rosa JC, Yamashita AS, Oliveira CR, et al. Chronic resistance training decreases MuRF1 and Atrogin1 gene expression but does not modify Ak and GSK$3 \beta$ and p70S6K levels in Rats. European J Appl Physiol 2009;106: 415-23. doi.10.1007/s00421009-1033-6

17. Dang K, Li YZ, Gong LC, Xue W, Wang HP, Goswami N, et al. Stable atrogin1 and murf1 gene expression is involved in the protective mechanism in soleus muscle of hibernating daurian ground squirrels Spermophilus dauricus. Biology Open 2016;5: 62-71. doi. 10.1242/bio.015776

18. Kafeshani M, Mirhosseini M, Momeni A, Rabiei $R$, Rafieiankopaei M. Impact of Kelussia odoratissima mozaffarian lipid profile and fasting blood sugar in hyperlipidemia patients. J Nephropharmacol2017;6: 9 .

19. Hoseini A. [The effect of eight weeks of curcumin supplementation on the expression of Some regulatory genes of atrophic processes in the heart tissue of fatty adult fatty Rats]. J Fasa Uni Med Sci 2019;9: 1425-32. (Persian). 